\title{
A Deep Impact on Louise Gluck's Poems: A Perspective View
}

\author{
Ms.Shruti Khare ${ }^{1}$, \\ $\mathrm{Ph}$ D Scholar, \\ Department of Arts \& Humanities \\ Madhyanchal Professional University, Bhopal \\ Dr.Vandana Singh ${ }^{2}$ \\ Associate Professor \\ Department of Arts \& Humanities \\ NRI College, Bhopal
}

Abstract: Louise Glück is the author of XII (twelve) poetry collections and a former Poet Laureate of the United States from 2003-2004. Her poetry is known for its intimate explorations of family relationships and the self, and also for how the poet juxtaposes the reconstructed lives of archetypal subjects from classic myths alongside personal revelations. Louise Glück, a poet from her debut collection, Firstborn (1968), has written 10 volumes, from A Village Life to her newest (2009). This survey is therefore confined to four early texts: The House on Marshland (1975), Descending Figure (1980); The Achilles Triumph (1985) and Ararat (1990). To understand the right appropriate language usage of the foreign language is necessary to be aware of these distinctions. Without that knowledge, we prefer to view and hear things by the categories that we know from our mother tongue in comfortable ways. The use of the language-cross intuition of translators may be considered systematic as indicated in the combination of the source and target language terms in the text of the corpus.
Keywords: Impact, perspective view, poetry, language etc

\section{Introduction}

Ararat is the name of the Jewish cemetery in the first book of Glück, the place where the parents and sisters of the poet are buried. It is also a memorial spot in which Glück recalls and learns to accept the tragedy of the past of his family. Ararat is also the name of the site where Noah's ark lay, a symbol of a new start following an enormous loss. Throughout Averno's last novel, Luck passes from the disturbing circumstances of her infancy to her philosophy of God, a terrible divorce and eventually death. The poet illustrates how poetry helps her heal emotional scars and to save her life along this trip. The final six volumes of the poet describe the steps of his journey from infancy and all the existential and spiritual lessons acquired as the poet draws to the conclusion of his life - a personal and ambitious overview of a desire for self-discovery and emotional healing. 
International Journal of Trends in English Language and Literature (IJTELL) An International Peer-Reviewed English Journal; Volume-2, Issue-3; 2021

At the conclusion of this voyage, the poet finally learns, without resorting to ultimate concepts of God, beauty or the fundamental importance of life, how to live. It is a poetic story that also acts as a symbolic reflection on the readers' own personal experiences, so that confidence and compassion is created between the poet and the reader, who may learn hard for the poet to apply to his own life.

With specific reference to 'Faithful and Virgin Night' I also like to highlight the psychological component in my study work. Many study articles on psychological aspects have been published in her poetry, however I don't think so and that is "Ignorance is happiness."

\section{Literature Review}

The writing term is applied to various works in dramatization and composition fiction which share practically speaking the feeling that the human condition is basically crazy, and that this condition can be satisfactorily addressed uniquely in works of writing that are they silly. The writing has its underlying foundations likewise in the developments of expressionism and oddity, just as in the fiction, written during the 1920s, of Franz Kafka (The Trial, Metamorphosis). [1]

The issues with people have given essayists their subjects for quite a long time. In our own assessments of three fundamental refrain modes, we have as of late suspected to be the reverence work (and the issues of energy, setback, unfairness), the commemoration (and the issues of death and mishap or ignoring), and the recognition (and the issues of social way of talking and stanza development). [2]

Mikhail Mikhailovich Bakhtin is step by step arising as one of the main masterminds of the 20th century. This case will strike numerous as lavish, since various variables have as of not long ago contrived to cloud his significance. Past the troubles as a rule going to the professions of amazing however whimsical scholars, there are for Bakhtin's situation, difficulties that are exceptional. [3]

Unscripted television is socially critical as in, until its appearance, verifiable programming had never prevailed as a reliable top of the line TV sort on British TV. From its start unscripted television tended to enormous crowds creatively, and it has kept up with its hang on the consideration of watchers, scholastics and those in the media businesses throughout a critical timeframe. [4]

The story is described a young woman who watched the film Snow White and the Seven Dwarfs curiously. Resulting to watching the film, she was stacked up with intensity and could scarcely contain herself. She went to her mother and retold the story - like her mother had never thought about it. Resulting to advising concerning how Prince Charming rode up on his white horse and kissed Snow White back to life - the youngster asked her mother, "Do you understand what happened then?" The mother said, "They lived blissfully ever after." The young woman scowled with frustration and said, "No - they got married."[5] 


\section{Problem Identification}

The basic point of problem identifications as per our dissertation work is as follows:

- Due to lack of descriptions of poem, difficulties may arise in teaching process.

- Due to dissimilarities of poem's structure in different languages, unable to understand the poem meaning.

- Proper prediction of poems in different languages is essential for understanding poems.

\section{Objective}

The basic points of objectives as per our dissertation work are as follows:

- To provide better descriptions and better teaching materials for language learners.

- To reduce the poem's structure conflicts for different languages

- To analyze the prediction of points in difficulties for understanding poems.

\section{Proposed Methodology}

The proposed method for contrastive analysis is as follows:

Step 1: Taking the two languages, L1 and L2, and writing formal descriptions of them.

Step 2: Picking forms from descriptions for the contrast.

Step 3: Making a contrast of forms chosen, and

Step 4: making a prediction of difficulty through the contrast.

To describe the prediction stage, stock well et al. (1965) propose a "hierarchy of difficulty" based on the notion of transfer (negative, positive, and zero).
When the structures of the given two languages are similar, positive transfer will occur while with those that are different, a negative transfer will take place.

When there is no relation between those structures of the two languages, zero transfer will occur.

The following criteria to establish the "preferred pedagogical sequence":

(1) Hierarchy of difficulty

(2) Functional load

(3) Potential mishearing

(4) Pattern congruity.

\section{Expected Outcome}

The expected outcomes are elaborated in following points:

- Describe the necessary psychological adjuncts of difficulty and then fitting the contrast to these adjuncts. In both cases, the relationship of the prediction to the contrast must be absolutely clear and provide better descriptions and better teaching materials for language learners.

- Formulation of a hierarchy of difficulty. In this case, one does not predict difficulty directly, but relative difficulty and reduce the poem's structure conflicts for different languages.

- The formulation of a prediction of difficulty or error, is that the step having the greatest practical interest to practitioners of the art and analyze the prediction of points in difficulties for understanding poems.

\section{References}

Abrams, M. H.,"A Glossary of Literary Terms", 4th Edition. New 
International Journal of Trends in English Language and Literature (IJTELL)

An International Peer-Reviewed English Journal; Volume-2, Issue-3; 2021

York, 1981.

Baker, David. "I'm Nobody: Lyric Poetry and the Problem of People." The Virginia Quarterly Review. Charlottesville: University of Virginia, Winter 2007.

Bakhtin, Mikhail,"The Dialogic Imagination: Four Essays", Austin: University of Texas Press, 1981.

Biressi, Anita and Nunn, Heather,"Reality TV: Realism and Revelation", London: Wallflower, 2005.

Boone, Joseph Allen, "Wedlock as Deadlock and Beyond", Chicago and London: The University of Chicago Press, 1987.

Booth, W. C., "The Rhetoric of Fiction", Chicago: University of Chicago Press, 1961, 2nd ed. 1983.

Breslin, Paul, "ThanatosTurannos: The Poetry of Louise Glück", Michigan: University of Michigan Press, 2005.

Brooks, Peter,"Reading For The Plot", Alfred A. Knopf: New York, 1984.

Cavalieri, Grace. "In the Magnificent Region of Courage: An
Interview with Louise Glück." Beltway Poetry Quarterly. Vol. 7, No. 4 (2006).

Christopher, Nicholas, "Art of Darkness" The New York Times. 12 Mar. 2006.

Colburn, Steven E., "With Barbara Kelves", No Evil Star: Selected Essays, Interviews, and Prose (Anne Sexton). University of Michigan Press: Michigan, 1985.

Costello, Bonnie, "Meadowlands: Trustworthy Speakers", On Louise Glück: Change What You See. Michigan: University of Michigan Press, 2005.

Culler, Jonathan, “Apostrophe",The Pursuit of Signs: Semiotics, Literature, Deconstruction. London: Routledge, 2001.

Eliot, T. S.,"The Varieties of Metaphysical Poetry", Ed. Ronald Schuchard. New York: Harcourt, 1993.

Feit Diehl, Hoanne, "Introduction On Louise Glück: Change What You See", Michigan: University of Michigan Press, 2005. 